\title{
THE INTERNATIONAL CRIMINAL TRIBUNAL FOR RWANDA: A PAPER UMBRELLA IN THE RAIN? INITIAL PITFALLS AND BRIGHTER PROSPECTS
}

\author{
By Jackson Nyamuya Maogoto*
}

\begin{abstract}
The tragedy which befell Rwanda in 1994 deserves a special place in the bloodstained pages of history. The Rwandan genocide merits distinction primarily because of its shocking efficiency, its scale and its proportional dimensions among the victim population. ${ }^{1}$ The Security Council's resolution establishing the ICTR articulates a set of decisions, assumptions, wishes, and objectives. ${ }^{2}$ Primarily, the States that voted in favour of the creation of the ICTR indicated that the root of the problem was individual violations of international criminal law. Only one State that voted for the resolution did not equate ipso facto ICTR actions with justice. That State considered the ICTR only one of the many tasks at hand for the international community. The ICTR was merely a vehicle of justice, "but it is hardly designed as a vehicle for reconciliation.... Reconciliation is a much more complicated process' (Czech Republic). ${ }^{3}$ Interestingly, Rwanda, which voted against the resolution, spoke of the problem in terms of a culture of impunity. ${ }^{4}$ The UN paid little to no heed to the subtle, but extremely different way in which the problem was characterised and the implications this would have on the type of tool needed to deal with that problem. ${ }^{5}$
\end{abstract}

\section{Introduction}

The genocide of 1994 was anything but a surprise for the international community. It was the culmination of many years of cynical indifference and wilful blindness to the plight of the Rwandan people. In the words of the then Rwandan representative to the Security Council: "Since 1959 Rwanda has repeatedly experienced collective massacres, which, as early as 1964, were described by Pope Paul VI and two Nobel

\footnotetext{
* LL.B (Hons) (Moi); LL.M (Cantab); PhD (Melb). Lecturer in law, University of Newcastle (Australia)

${ }^{1}$ The number of persons killed throughout the territory is to be numbered in the hundreds of thousands, estimates ranging from 200,000 to 500,000. In fact, even the latter figure is probably less than the reality. Some observers think that the figure is close to a million. It is not sure that the exact number of victims will ever be known.

${ }^{2}$ SC Res 955, UN SCOR, 49th Year, 3453rd mtg., UN Doc S/RES/955 (1994).

${ }^{3}$ UN SCOR, 49th Sess, 3453d mtg, UN Doc S/PV.3453 (1994) 7.

${ }^{4}$ Ibid, para. 14.

5 The ICTR's sister tribunal in Yugoslavia, the ICTFY, was clearer about what it believed to be its objectives by interpreting its mandate from the Security Council. They are, to bring to justice those responsible; to contribute to ensuring that such violations are halted and effectively redressed by acting as a powerful deterrent to all parties against continued participation in inhuman acts; to gradually promote an end to armed hostilities; to be a tool for promoting reconciliation by working to attribute acts to individuals and thereby provide justice to individual victims to diminish group hatred and the need for revenge. See First Annual Report of the International Tribunal for the Prosecution of Persons Responsible for Serious Violations of International Humanitarian Law Committed in the Territory of the Former Yugoslavia Since 1991, in ICTFY Year Book (1994) 81, 86-87, UN Sales No E.95.III.P.2. The UN Legal Counsel Carl August Fleischhauer stated that the tribunal was set up with three aims: ending war crimes, bringing perpetrators to justice, and breaking the cycle of ethnic violence and retribution. See Andrew Kelly, 'Yugoslavia War Crimes Tribunal Starts Work'. Chicago Sun-Times, 18 November 1993, 52.
} 
Prize winners - Bertrand Russell and Jean-Paul Sartre - as the most atrocious acts of genocide this century after that of the Jews during the Second World War. But whenever such tragedies occurred the world kept silent and acted as though it did not understand that there was a grave problem of the violation of human rights." ${ }^{\circ}$ Thus in 1994, the international community became a spectator to an archetypal genocide, the attempted extermination of an entire people.

The slaughter required extensive administrative and logistical planning, evidenced by the chillingly calculated and thorough way in which it was carried out, and by the fact that most of the victims - between 500,000 and 1 million mainly Tutsi persons as well as politically moderate Hutu leaders and their families ${ }^{7}$ - were killed over the relatively short period from 6 April through the first three weeks of May 1994. This death toll amounts to roughly ten percent of the Rwandan national population. ${ }^{8}$ Notwithstanding the 'low-tech' nature of the massacres, (Victims were butchered with machetes (panga), sticks, tools, and large clubs studded with nails (masu) $)^{9}$ "[t]he dead of Rwanda accumulated at nearly three times the rate of Jewish dead during the Holocaust. It was the most efficient mass killing since the atomic bombings of Hiroshima and

\footnotetext{
${ }^{6} \mathrm{UN}$ Doc S/PV.3453 (1994), supra note 3, paras. 13-14.

${ }^{7}$ See Report of the Situation of Human Rights in Rwanda Submitted by Mr R Degni-Sequi, Special Rapporteur of the Commission on Human Rights, UN ESCOR Commission on Human Rights, 51st Sess, Prov Agenda Item 12, para 24, UN Doc E/CN.4/1995/7 (1994) para. 24.

${ }^{8}$ See P. Gourevitch, We Wish to Inform You That Tomorrow We Will Be Killed with Our Families: Stories from Rwanda (Farrar, Strauss \& Giroux, New York, 1998) 4 ('Decimation means the killing of every tenth person in a population, and in the spring and early summer of 1994 a program of massacres decimated the Republic of Rwanda.').

${ }^{9}$ See M. H. Morris, 'The Trials of Concurrent Jurisdiction: The Case of Rwanda,' 7 Duke Journal of Comparative and International Law (1997) p. 350.
} 
Nagasaki". ${ }^{10}$ The genocide was the culmination of several prior mass killing orgies. It was a well-organised and coordinated event. ${ }^{11}$

Immediately preceding and during the Rwandan genocide, the political instrumentalisation of ethnicity was so focused and so pointed that Hutu were led to believe - and many actually believed - that they were doing good by killing Tutsi. The genocide was not about ethnic identity operating as a constitutive element of Rwandans' personal identity. Rather, the genocide was about ethnicity operating coercively as the unwavering, singular expression of good or evil, of 'us' and 'them'. ${ }^{12}$

The International Criminal Tribunal for Rwanda (ICTR) grew out of the response of the UN human rights system to the Rwandan tragedy. Parallel to the efforts within the UN human rights system, the government of Rwanda that came to power by toppling the genocidal regime ${ }^{13}$ made a request to the UN Security Council for assistance to bring those responsible for the genocide to justice. ${ }^{14}$ Based on its concern that the serious and extensive human rights violations in Rwanda would disrupt international peace and

\footnotetext{
${ }^{10}$ Gourevitch, supra note 8, p. 4. "That's three hundred and thirty-three and a third murders an hour - or five and a half lives terminated every minute." Ibid, p. 133. Of course, to these numbers have to be added the "uncounted legions who were maimed but did not die of their wounds, and the systematic and serial rape of Tutsi women," ibid, in order to fully grasp the numbers of aggressive participants and victims in the genocide.

${ }^{11}$ Most of the individuals responsible for carrying out violations of human rights and humanitarian law fled the country amongst the over 2 million that sought refuge in the neighbouring countries of Burundi, Zaire and Tanzania, for fear of possible Tutsi reprisals and revenge attacks. Numerous criminal suspects fled to Francophone West African countries, as well as to Kenya, and as far away as Belgium, Canada, France, Switzerland and the United States.

${ }^{12}$ M. A. Drumbl, 'Punishment, Postgenocide: From Guilt To Shame To Civis In Rwanda', 75 New York University Law Review (2000) p. 1294.

${ }^{13}$ The Rwandan Patriotic Front took power in July 1994. For an overview, see Gerard Prunier, 'The Great Lakes Crisis', 96 Current History (1997) p. 193.

${ }^{14}$ Letter Dated 28 September 1994 from the Permanent Representative of Rwanda Addressed to the President of the Security Council, UNSCOR, 49th Sess, UN Doc S/1994/1115 (1994) 4.
} 
security, ${ }^{15}$ the Security Council invoked its Chapter VII authority under the UN Charter and established the ICTR "for the sole purpose of prosecuting persons responsible for genocide and other serious violations of international humanitarian law committed in the territory of Rwanda, and Rwandan citizens responsible for genocide and other such violations committed in the territory of [neighbouring] States, between 1 January 1994 and 31 December 1994."16 The preamble of the Resolution states the main objectives of the International Tribunal to be those of accountability, deterrence and a desire to contribute to national reconciliation and the maintenance of peace. It is against these objectives that the performance of the ICTR should be gauged. ${ }^{17}$ As indicated by the preambular paragraphs of Security Council Resolution 955 of 1994, the ICTR hopes to deter the culture of impunity by confronting it with accountability and thus defusing the cyclical waves of mass killings that plague Rwanda.

\footnotetext{
${ }^{15}$ Serious human rights violations implicate Chapter VII jurisdiction. See L. R. Beres, 'Iraqi Crimes During and After the Gulf War: The Imperative Response of International Law' 15 Loyola of Los Angeles International and Comparative Law Journal (1993) p. 325; B. M Tocker, 'Intervention in the Yugoslav Civil War: The United Nations' Right to Create an International Criminal Tribunal', 12 Dickinson Journal of International Law (1994) p. 527.

${ }^{16}$ See SC Res 955, supra note 2. See also L. D. Johnson, 'The International Tribunal for Rwanda', 67 Revue Internationale de Droit Penal (1996) p. 211; L. S Sunga, 'The Commission of Experts on Rwanda and the Creation of the International Criminal Tribunal for Rwanda', 16 Human Rights Law Journal (1995) p. 121.

${ }^{17}$ The Preamble of SC Res 955, supra note 2, provided in part:
}

The Security Council,

... Expressing once again its grave concern at the reports indicating that genocide and other systematic, widespread and flagrant violations of international humanitarian law have been committed in Rwanda, ...

Determined to put an end to such crimes and to take effective measures to bring to justice the persons responsible for them,

Convinced that in the particular circumstances of Rwanda, the prosecution of persons responsible for genocide and the above-mentioned violations of international humanitarian law would enable this aim to be achieved and would contribute to the process of national reconciliation and to the restoration and maintenance of peace,

Believing that the establishment of an international tribunal for the prosecution of persons responsible for the above-mentioned violations of international humanitarian law will contribute to ensuring that such violations are halted and effectively redressed.... 
The ICTR was intended to bring justice to the most serious perpetrators of the genocide and other violations of international humanitarian law and to ensure that such violations do not reoccur. ${ }^{18}$ However, while courts are needed to enforce law, courts, however, do not and cannot make human rights real. The achievement of human rights is a much more complex process than the establishment of a court. While the Rwanda tribunal responded to the lawyer's gradualist approach to institutional and normative development of international criminal law, it initially failed to successfully address the basic purposes for which it was established, to end impunity and deter potential offenders. It has been hampered by conceptual considerations.

To delve more deeply into the ICTR's handicap in addressing the human right's situation in Rwanda through the international penal process, this Article makes use of a distinction of looking at human, social or for that matter world affairs: the actororientated and structure-orientated perspectives. ${ }^{19}$ They can be seen as two ways of reflecting, and reflecting on, social affairs and legal tradition, each of them focusing on different aspects. The legal paradigm (especially criminal law) is biased in favour of the actor-oriented perspective due to its simplistic concreteness, identification of the evil actor, apprehension and prosecution. This Article sets out to consider the initial focus of the ICTR on classical criminal law theory and the failings of this in fulfilling the broader objectives of the international penal process which transcend the prosecution and conviction of guilty persons. The Article then moves on to consider the significance of restorative justice paradigms in reconstructing the post-genocidal society before concluding with positive trends and transformations that the international and domestic

\footnotetext{
${ }^{18}$ Ibid. paras. 1-2.

${ }^{19}$ J. Galtung, Human Rights in Another key (Polity Press, Cambridge, UK, 1994) 26-49.
} 
processes adopted after a realisation of the limited scope of criminal trials in addressing the genocide.

\section{The Rwandan Genocide: An Event or a State of Affairs}

The first prosecutor of the ICTR held views that are generally similar to those of many within the prosecutorial profession. He believed the fear of detection, financial penalties, and indignities of guilt were at the centre of criminal justice. Like most prosecutors, he placed the judicial response at the top of the hierarchy noting, “... all criminal lawyers will agree, detection and punishment are the only means by which to curb criminal conduct." ${ }^{20}$ Being that the ICTR prosecution office was largely focused with what to do with the evil actors, the answer was necessarily threefold; converting them to better intentions, weakening them by depriving them of capability and/or making them more passive in general. The rude reality though is that the trials and convictions of the then 53 indictees ${ }^{21}$ on the ICTR's list of shame would not have some kind of legal domino effect on the acts and intents on the rest of the perpetrators numbering tens of thousands, many of whom were (and still are) active in guerrilla-style military incursions against the Tutsi-dominated government in power.

Obviously the mass murders in Rwanda did not arise spontaneously. They were instigated by persons in positions of power who sought to gain personal advantages through violent and hideous means. Unless these persons are held accountable for their crimes against humanity, the reconciliation necessary for the reconstruction of this torn

\footnotetext{
${ }^{20}$ Justice R. Goldstone, 'Conference Luncheon Address: Prosecuting International Crimes: An Inside View' 7 Transnational Law and Contemporary Problems (1997) p. 2.

${ }^{21}$ See 'Press Briefing by the Spokesman for the ICTR', 19 October 2000, Doc. ICTR/INFO-9-13-018, http//www.ictr.org/ENGLISH/pressbrief191000.html, visited 20 March 2000.
} 
society may not be possible. By assigning guilt to the leader-instigators, the tribunal may also lift the burden of collective guilt that settles on the Hutus, whose leaders directed or ordered such terrible violence. The assignment of guilt by a neutral tribunal may also enable the international community to differentiate between victims and aggressors. However the international justice process could not erase the fact that the interethnic conflict while not genetically inbred, is firmly embedded in the sociocultural structure and subconscious of the Rwandan society and thus addressing this structural defects is part of the process of deterrence.

The initial sole focus on the ICTR indictees was unrealistic and demonstrated that the Tribunal was unclear about why it existed and how it could make its modest contribution for the betterment of human rights in the region. ${ }^{22}$ There is an abundance of the 'evil' ones, those who have already through their acts proved that they are evil, as well as those who may be suspected of harbouring evil intentions. The causes of the Rwandan tragedy rest with them, expressed in their acts or threats or general inclination to engage in evil acts but the fact is that the international penal process will only try a minuscule fraction of the whole group of perpetrators, the indictees. ${ }^{23}$ So many people were killed principally because there were so many killers. Significant numbers of Rwandans perpetrated the bloodbath. What induced so many individuals to participate was not coercion, but rather genuine support of the idea that the Tutsi had to be eliminated, together with the pursuit of solidarity with others in attaining this goal. This belief that one was doing right by killing explains why so many of the killings were so

\footnotetext{
${ }^{22}$ T. Howland \& W. Calathes, 'The UN's International Tribunal, Is It Justice or Jingoism for Rwanda', 39 Virginia Journal of International Law (1998) p. 148.
} 
brutal. ${ }^{24}$ Many Hutus believed that killing the Tutsi was a civic duty - in other words, nothing less than the right thing to do. ${ }^{25}$ An even larger number of people acquiesced in the face of genocide. The killings were committed publicly and were known to all. ${ }^{26}$ They 'did not take place at out-of-the-way sites...[but] throughout the country: in virtually every village and in almost every urban neighbourhood'. ${ }^{27}$ The indirect or direct participation of so many people in the Rwandan genocide blurs the line between guilt and innocence.

In order to perform the genocide, the Hutu leaders over the years succeeded in organising a campaign that redefined the Tutsis (the victim group) as worthless, outside the web of mutual obligations, a threat to the Hutu hegemony, and in the run-up to the 1994 genocidal conflagration, as subhuman. Even after such a campaign of vilification and dehumanisation ${ }^{28}$ the actual performance of the mass killing required a good deal of coercion and centralised control that converted a large segment of the Hutu populace

\footnotetext{
${ }^{23}$ One Africanist estimates that the number of Rwandans directly involved in the acts of killing amounted to between 75,000 and 150,000. V. Jefremovas, 'Acts of Human Kindness: Tutsi, Hutu, and the Genocide' 23 Issue (1995) p. 28.

${ }^{24}$ For case studies of such incidents, see Human Rights Watch/Africa et al., Shattered Lives: Sexual Violence During the Rwandan Genocide and Its Aftermath (Human Rights Watch, New York, 1996) pp. 42-68; see also Prunier, supra note 13, pp. 255-57 (describing types of brutal acts committed).

${ }^{25}$ For a description of slaughter as civic duty in Butare prefecture, see A. Des Forges, Leave None to Tell the Story: Genocide in Rwanda (Human Rights Watch, New York, 1999) p. 515.

${ }^{26}$ Ibid, 770 (discussing broad advertisement of killings).

${ }^{27}$ A. Neier, 'Rethinking Truth, Justice, and Guilt After Bosnia and Rwanda' in C. Hesse \& R. Post (eds), Human Rights in Political Transitions: Gettysburg to Bosnia (Zone Books, New York, 1999) p. 48.

${ }^{28}$ The renowned African scholar, A. A. Mazrui, noted that 'violations of human rights are preceded by a process of psychic sub humanisation' by which the violator 'sub humanises his victim in his own imagination,' although 'residual humanity is often necessary to give meaning to the sin of inter-human cruelty'. Such dehumanisation, he explained, is the 'reverse of the psychology of love' because no human being can love a non-human object 'unless the object undergoes psychic humanization in the imagination of the lover'. When someone loves her dog 'it is because the dog has been, in some sense, anthropomorphized,' and when someone loves his 'motherland' it is because his imagination 'has invoked a metaphor of human kinship' with the territory. The psychology of hate, on the other hand, requires 'a partial reduction of humanity'. Since it is difficult to hate an inanimate object or animal, the most fertile soil for hatred is that 'intermediate area of sub-humanity' or 'tendency on the part of the hater to reduce the humanity of the person hated'. A. A. Mazrui, Human Rights and the Moving Frontier of World Culture, in Philosophical Foundations of Human Rights (UNESCO, Paris, 1986) p. 243.
} 
into a band of mass killers and thus criminals. While much was initially said about the pragmatic dimension of punishing mass human rights violations through prosecutions as a preventive measure no paradigm was set out in relation to the task of post-conflict peace-building which entails a psychological dimension of justice and reconciliation.

The ICTR's initial almost exclusive focus on concrete entities; the individual as a building block of the genocidal reality was distorting and obscuring the structural reality that converted tens of thousands of Hutus into a mass of killers, turning on their friends, neighbours and colleagues. ${ }^{29}$ The 1994 genocide followed three earlier rounds of massacres targeting Tutsis in 1959, 1963 and $1966 .{ }^{30}$ The 1994 bloodbath was preceded by a macabre dress rehearsal in 1992. ${ }^{31}$ With preparations complete, in 1994 the government was able to manipulate the structure founded on sharp, ethno-centric rift by fuelling the hatred through national radio (Radio Television Libre des Mille Collines) broadcasts that dehumanised the Tutsis as 'inyenzi' (cockroaches), ${ }^{32}$ facilitating the creation of an effective killing machine that stretched from the city suburbs to remote farms in the village.

\footnotetext{
${ }^{29}$ Jefremovas, supra note 23, p. 21.

30 The UN Special Rapporteur observed in 1994: "The Rwandan have indeed been the victims of a number of massacres in the past, notably in 1959, 1963, 1966, 1973, 1990, 1991, 1992 and 1993. However, those being perpetrated at present are unprecedented in the history of the country and even in that of the entire African continent. They have taken on an extent unequalled in space and in time." Report of the Situation of Human Rights in Rwanda supra note 7, para. 20.

${ }^{31}$ On 1 October 1990, the insurgent RPF crossed the Ugandan border and carried out several military operations in the north of Rwanda. Out of revenge, Hutu groups killed some 300 Tutsis in the following weeks. By 1992, over 350,000 persons had fled the violence in the northern regions of Rwanda, becoming displaced in the interior of Rwanda.

${ }^{32}$ The term 'inyenzi' is Kinyarwanda for cockroach. The widespread use of the term in radio broadcasts was initially to denounce supporters and sympathisers of the Rwanda Patriotic Front (overwhelmingly Tutsis and moderate Hutus). In time it conferred the de facto meaning of 'persons to be killed'. Within the context of the Civil War of 1994, the term 'inyenzi' became synonymous with the term 'Tutsi'. See the Ruggiu Judgment, The Prosecutor v. Georges Ruggiu, ICTR-97-32, para. 44.
} 
This process of dehumanisation was a contrivance of populist leaders which feed on the primitive impulse to denigrate the Tutsis as a means of self-affirmation. Before ordinary Hutu could participate in the slaughter of defenceless men, women and children, the Tutsi had to be portrayed as an inherently bloodthirsty and cruel people out to break the Hutu hegemony through violence and thus, it was necessary to launch preventive measures, which incidentally took the form of preventive violence. The Hutus were spurred on by exhortations appealing to them as a collectivity to preserve their ethnic hegemony by eliminating all sympathisers and supporters of the Rwandan Patriotic Front (RPF) whose military successes had forced the government onto the negotiation table. $^{33}$

For many though, the ICTR would establish individual guilt and thereby move suspicion and blame from the group to the individual. It was a laudable goal, but a complex one in the circumstance. For crimes to be crimes there must be an individual act. These crimes may or may not be part of a criminal enterprise. When a crime is part of a criminal enterprise, the nature of the relation between the individual, crime, and society profoundly changes. ${ }^{34}$ Any penal response to a criminal enterprise must

\footnotetext{
${ }^{33}$ Motivated to regain their former position of prestige in the country, and concerned to aid their brothers and sisters in Rwanda from the recurrent violence perpetrated against them, Tutsi paramilitary forces coalesced into the Rwandan Patriotic Front (RPF). The RPF launched small-scale incursions from neighbouring countries into Rwandan territory in order to force the Hutu dominated government towards power- sharing. By 1993, it was clear to the Hutu Government that the Rwandan Patriotic Front had become an insurgency movement capable of destabilising Rwanda and that it would be prudent to explore the possibilities of a cease-fire. Negotiations between the Government of Rwanda and the Rwandan Patriotic Front commenced at Arusha, Tanzania, on 10 August 1992.

${ }^{34}$ When people engage in crime as a series or pattern of illegal acts which result in an uneven or incomplete meting out of punishment, some implicit or explicit accommodation must be made within any criminal justice system. This process of compromising law enforcement involves a wide range of considerations with direct impact on the organisational pattern and structure, which can be traced to the nature of law itself. See C. H. McCaghy and S. A. Crime in American Society (Macmillan, New York, 1987).
} 
understand the entire crime and its relation to society to begin to address it effectively through the justice system. ${ }^{35}$

Within the ICTR's early framework of thinking, the genocidal acts by extremist Hutus were seen as an event, not a state of affairs; something that was is and probably will continue to lurk in the sub-consciousness of the extremists. It may be a slowly or quickly changing state of affairs, depending on the circumstances, key among which is the process of the extremists reclaiming back political and military authority in Rwanda. The war in Rwanda is unfinished; there was not even a temporary respite after the genocide, before the Hutu-Tutsi struggle for the control of the State resumed. There is little doubt in this context that the ICTR was largely seen by Hutus, as international punishment by the victors, Tutsis with the blessing and support of the United Nations. ${ }^{36}$ Tutsis may themselves see the Tribunal and the genocide trials they are conducting in

\footnotetext{
${ }^{35}$ Criminal enterprise behaviour is a type of behaviour that invariably arises as a natural social phenomenon in nearly every society. It is a social epidemic that takes different forms at different times across these societies, but because its etiology so differs from that of individual criminal behaviour, its effect on society and its demand of a response from the justice system is markedly different as well. Crime as part of a criminal enterprise almost always results in selective and discriminatory enforcement of laws. The use of discretion in dealing with these offences by a criminal justice system offers an opportunity for criminal forces to strongly influence the justice process itself. In a sense, a functional 'tolerance policy' by law enforcement bureaucracies may develop and often does. When responding to crime as part of a criminal enterprise, social control bureaucracies are confronted with the vexing problem of enforcing laws about which little, sporadic, or inconsistent social consensus among society's many groups may be discerned. See J. R. Gusfield, Symbolic Crusade: Status Politics and the American Temperance Movement (University of Illinois Press, Urbana, 1963). The community's ruling elite inevitably finds itself in an odd position, a position which potentially can severely challenge its authority as a justice insurer. The ruling elite must select which values within the community it must advance and then either selectively enforce laws and punishments, or attempt to obliterate a portion or all of the class of violators. Irrespective of this problem, if a justice system is to respond in an effective way to organised, crimes it must seek, quite naturally, to develop its coalition of support in order to expand not only its budgetary/personnel resources and their enforcement power, but its will to pass and enforce laws proscribing the offensive behaviours. See H. S. Becker, Outsiders: Studies in the Sociology of Deviance (Free Press, New York, 1963).

${ }^{36}$ Credibility of the Rwanda Tribunal is unlikely to materialise among Hutus because they are its main targets. The prosecution of Tutsis is essential for the tribunal's legitimacy. In the case of the Yugoslav Tribunal, the prosecution of Bosnians and Croats - and not just Serbs - would enhance that tribunal's legitimacy in the eyes of perpetrators across the board.
} 
Rwanda as their opportunity for revenge. ${ }^{37}$ The ICTR being initially obsessed by a need to be neutral and independent distanced itself from the overall political settlement of the Hutu-Tutsi struggle for political power and thus was virtually irrelevant to the future of Rwanda. ${ }^{38}$

What the ICTR (and the international community) hoped to achieve in the euphoric early days of the ICTR soon fell victim to the reality of the structural underpinning of the genocide. The ICTR hoped to bring about a discontinuous jump, by breaking the vicious cycle of human rights violations through an international presence that was little felt in Rwanda itself. It was not apparent then that the deep-seated animosity between the two segments of the Rwandan population would not dispel easily by a few years of international justice. The animosity and hatred was cultivated, reinforced and manipulated for over six decades by the colonial powers, then well nurtured by the Hutu leaders who ascended to power after independence. It has taken close to a century to achieve a well-entrenched social structure pegged on ethnic stratification, founded on deep-seated hatred. ${ }^{39}$ This is not to say that the effort at prosecution is an exercise in futility. Obviously there are actors around otherwise the structure would not operate. Individual guilt, leading to prosecution is important, but it should not detract from the flaws in the Rwandan social structure. The actor-oriented perspective draws its strength from its simplistic concreteness; its ability at capturing concrete actors; the individuals. But only a segment of an actor is in the structure, and only a part of the structure shows

\footnotetext{
37 P. Akhavan, 'The International Criminal Tribunal for Rwanda: The Politics and Pragmatics of Punishment' 90 American Journal of International Law (1996) p. 508. It is interesting to note that the RPF government wanted the Rwanda Tribunal situated in Rwanda so that it would teach the 'Rwandan people a lesson, to fight against the impunity to which it had become accustomed ... and to promote national reconciliation'. But this is only possible if the tribunal enjoys some credibility with the perpetrators.

${ }^{38}$ A. D. Lowell, 'Nuremberg in Rwanda: Not Enough' Legal Times, 3 April 1995, pp. 23-25.
} 
up in any one particular actor. While the ICTR's indictees may have been architects of the genocide, they simply tapped into the huge reservoir of ethno-centric hate that had been entrenched in the sub-consciousness of Hutu's converting a great deal of them into pathological killers.

Having a positive impact on a complex socio-political process is not the same as successfully prosecuting a person for a criminal violation of human rights law in accord with the law. Only by seeking to address the causal factors of the genocide would the ICTR translate its prosecutorial victories into victory for human rights in Rwanda. The ICTR initially failed to provide an institutional framework that would contribute to the extremely complex process of moving a society from one characterised by massive human rights violations to one built upon the respect of human rights law. A key oversight in the ICTR's prosecutorial strategy was its failure to seek to address the accumulation of collectively organised evil within the Rwandan society, entrenched over a period of almost one century. ${ }^{40}$

\section{A Leaky Sieve? The Pitfalls of Classical Criminal Law Theory}

Virtually all theories of criminal justice can be characterized as either retributive or deterrent (utilitarian). ${ }^{41}$ For utilitarians punishment is justified to the extent it produces a socially desirable consequence, ordinarily general deterrence. ${ }^{42}$ In contrast,

\footnotetext{
${ }^{39}$ See Part II of the Article.

${ }^{40}$ See generally A. Destexhe, Rwanda and Genocide in the Twentieth Century, trans. A. Marschner (New York University Press, New York, 1995); Prunier, supra note, p. 13.

${ }^{41}$ See J. Rawls, 'Two Concepts of Rules' in Robert M Baird \& Stuart E Rosenbaum (eds), Philosophy of Punishment (Prometheus Books, Buffalo, 1988), 38; W. de Haan, The Politics of Redress: Crime, Punishment and Penal Abolition (Unwin Hyman, London, 1990) p. 103, noting that all theories of punishment are based on retribution and deterrence.

${ }^{42}$ See J. B. Cederblom, 'Introduction' in J. B. Cederblom \& W. L. Blizek (eds) Justice and Punishment (Ballinger Publishing Co, Cambridge, MA, 1977) p. 3.
} 
consequences are irrelevant for retributionists. Rather they consider it simply morally fitting that criminal offenders are punished. ${ }^{43}$ Described by R. Solomon, "the desire for retribution is the desire for vengeance (,)...getting even, putting the world back in balance". ${ }^{44}$ The international penal process at the ICTR was initially firmly focused on deterrent and retributive aspects of the criminal process with little pragmatic effort to incorporate rehabilitative and restorative aspects into its overall strategy.

\section{The Deterrence Theory}

Whether the offence is tax evasion or genocide, deterrence theory presupposes a rational, utility-maximizing actor. Persons commit crimes, so the theory goes, when the expected value of doing so exceeds the cost of punishment. To reduce crime, society need only raise the price by imposing harsh penalties. The complexity of the Rwandan situation and the operations of the ICTR would frustrate those who advocate punishment as deterrence. Societies engulfed by mass political violence are not particularly conducive to rational behaviour or fears of eventual apprehension. How can we expect individuals to make a rational choice calculus when they are surrounded by hysteria, social chaos, panic, coercion, prejudice, and a government that is exhorting mass violence ${ }^{45}$ Layered on top of the irrational context in which mass violence

\footnotetext{
${ }^{43}$ See W. Berns, 'The Morality of Anger' in Philosophy of Punishment', supra note 41, p. 85 (stating that we punish criminals principally to pay them back).

${ }^{44}$ R. C. Solomon, A Passion for Justice: Emotions and the Origins of the Social Contract (AddisonWesley Publishing Co, Reading, MA, 1990) p. 41.

${ }^{45}$ Yet the ICTR and the ICTY seek to achieve this goal of utilitarian deterrence. See W. Schabas, 'Justice, Democracy, and Impunity in Post-Genocide Rwanda: Searching for Solutions to Impossible Problem', 7 Criminal Law Forum (1996) pp. 523, 461, 498 (stating that: [R]eferring implicitly to the notion of deterrence, the Security Council affirmed its conviction that the work of the two tribunals 'will contribute to ensuring that such violations are halted'. The effective prosecution and punishment of offenders is therefore intended to deter others from committing the same crimes, and perhaps to convince those already engaged in such behaviour that they should stop. (footnote omitted) (quoting Statute of the ICTY). The judgments of the ICTR reveal the importance the tribunal accords to deterrence. See Prosecutor v. Rutaganda, Case No ICTR-96-3, paras. 475, 6 December 1999, http://www.ictr.org/, visited 20 December 2000 (stating that: "[T] he penalties imposed on accused persons found guilty by the
} 
operates is the reality that an individual's decision to act violently may not be perceived as a legal or even a moral wrong. When taken together, these two factors support the conclusion that choices to participate in mass violence well may be only slightly, if at all, deterred by the prospect of eventual prosecution - especially if undertaken by some distant international tribunal. If those committing the barbarities do not expect to lose power to the victims (or to third parties such as international authorities), they may not take the threat of penal sanction very seriously. ${ }^{46}$

Punishments even if they are imposed to any real extent by the ICTR, will be meted out slowly, given limited resources. ${ }^{47}$ The fact that cases are handled in a slow and circuitous manner contravenes the axiom that for deterrence to work punishments must be meted out with swiftness and certainty. ${ }^{48}$ It is unrealistic to presuppose that a nascent institution operating in the Rwandan genocidal context could act efficiently enough for the desired deterrent impact to be realised. Approximately 125,000 individuals - roughly ten percent of the adult male Hutu population - are incarcerated in Rwandan jails designed to hold $15,000 .^{49}$ At the present rate of national trials, it would take hundreds

\footnotetext{
Tribunal must be directed,... at deterrence, namely to dissuade for ever [sic], others who may be tempted in the future to perpetrate such atrocities by showing them that the international community shall not tolerate the serious violations of international humanitarian law and human rights."); Prosecutor $\mathrm{v}$ Musema, Case No ICTR-96-13-T, para. 986, 27 January 2000, http://www.ictr.org/, visited 20 December 2000.

${ }^{46}$ See M. Minow, Between Vengeance and Forgiveness: Facing History After Genocide and Mass Violence (Beacon Press, Boston, 1998) p. 50. ("Individuals who commit atrocities on the scale of genocide are unlikely to behave as 'rational actors,' deterred by the risk of punishment.").

${ }^{47}$ Howland and Calathes, infra note 22, p. 151.

${ }^{48}$ J. H. Burns and H. L. A. Hart (eds) Jeremy Bentham, An Introduction to the Principles of Morals and Legislation (Oxford University Press, Oxford, 1970); G. R. Newman, Just and Painful (McMillan, New York, 1983).

${ }^{49}$ See Integrated Reg'l Info Network for Cent \& E Afr (IRIN-CEA), United Nations Office for the Coordination of Humanitarian Affairs (UN OCHA), Update No 509, 24 September 1998, http://www.reliefweb.int/IRIN/index.phtml, visited 30 December 2002; Drumbl, supra note 12, p. 571; Morris, supra note 5, p. 352.
} 
of years to adjudge all of these detainees. ${ }^{50}$ The ICTR was not of much help either in reducing the number of detainees, by late 2000, after spending over 200 million dollars; it had indicted 53 individuals and heard only nine cases. ${ }^{51}$

Seemingly, the ICTR's presence was not having the intended sobering effect on the Hutu extremists. This would be largely because the general stance of the international community was to view the genocide in terms of a sudden event, the evil act of the evil actor, and thus the international penal process is seen as a remedy. But the evil act rests within a large part of the population, something permanent, the permanent evil intent among extremists in both groups wrought by a volatile social structure pegged on deepseated animosity that has spawned a strong culture of hatred and ethnic rift.

While the creation of the ICTR may have a lasting effect on the application of humanitarian law to both international and domestic conflicts and accomplish what its first Prosecutor Goldstone stated, as the significant task of and human rights squarely on the international agenda, ${ }^{52}$ the Tribunal ran the risk of not making a significant contribution if it failed to generate substantial appreciation on the part of Hutus of the extreme criminality of acts of the mass killings, or with regard to the Tutsis, the fact that reciprocal counter-measures whether low intensity or not, amount to crimes based on the same legal standards that the Hutus face.

\footnotetext{
${ }^{50}$ See J. C. McKinley, Jr, 'Massacre Trials in Rwanda Have Courts on Overload', New York Times, 2 November, 1997, § 1, 3 .

${ }^{51}$ See International Criminal Tribunal for Rwanda, http://www.ictr.org, visited 16 September 2000; see also J. Prendergast \& D. Smock, US Institute of Peace, 'Postgenocidal Reconstruction: Building Peace in Rwanda and Burundi' (1999), http://www.usip.org/oc/sr/sr990915/sr9990915.html, visited 9 December 2000 .
} 
It is not enough that the international penal process classifies the behaviour as wrong, extremely distasteful and the acts as international crimes. Until the Hutus (and extremists among the Tutsis who may have a vision of grand vengeance) are capable of doing so, they will not abstain from the act, risk of bad conscience or the risk of the State or international community applying normal standards built into national law and international treaties. Thus the extremists see their post-genocidal intention and actions in another direction, killing yes, but not with the intent of wiping out the other group, but with the intention of avenging their own personal losses, and furthering themselves and their ethnic hegemony through erosion and attrition of the other group in numbers. As Professor M. Drumbl notes:

\begin{abstract}
"Many [domestic] detainees see themselves as prisoners of war, simply ending up on the losing side. In fact, the prisoners do not even call the events of April to July 1994 the 'genocide,' but, instead, refer to these events as 'the war." 53
\end{abstract}

\title{
The Retributive Theory
}

Retributionists believe that if offenders are not punished for their crimes, then other people will not respect the criminal law and not obey it. For this school of thought, the focus is on the development of strategies for administering the courts, the police and the prisons more effectively. ${ }^{54}$ Retribution attracts people that want a quick fix crime solution. Its usefulness as a tool for building a strong culture of justice in post-genocide Rwanda society was therefore limited. Retribution merely shifts the revenge over from

\footnotetext{
${ }^{52}$ C. Tyler, 'Bloodhound in Pursuit of the Dogs of War: Christian Tyler Meets Richard Goldstone, Chief Prosecutor of the UN War Crimes Tribunal', Financial Times, 2 March 1996.

${ }^{53}$ Drumbl, 'From Guilt to Shame', supra note 12, p. 607. Conflating the genocide with the war against the RPA contains faulty reasoning. See Gourevitch, supra note 8, pp. 98-99 ('[A]lthough the genocide coincided with the war, its organization and implementation were quite distinct from the war effort.').

${ }^{54}$ See, eg, P. J. Benekos, 'Public Policy and Sentencing Reform: The Politics of Corrections' Federal Probation, March 1992, 4-5.
} 
the individual to the State (and Tribunal). ${ }^{55}$ The ICTR was imbued with like sentiment and the characteristic self-righteous tenor of those striving to secure the 'deserved' punishment of others. This is not surprising, a look at Security Council proceedings regarding the aims of the ICTR unearths a majoritarian view by participating States favouring the 'just desserts' discourse. ${ }^{56}$ There is perhaps no greater canard than the idea that punitive justice provides needed therapy for individuals; that nothing can assuage anger or restore dignity like punishment. The emphasis on victimhood, blame, and powerlessness may actually undermine recovery from violent crime.

The willingness to punish the unusual is a basic criminal law philosophy. But if an actor commits an act that can be seen as 'normal' in the precise sense that the other actors in the same position would commit the same acts in the same situation, the justice process is then seen as motivated by vengeance. Mass violence constitutes what C. S. Santiago Nino, citing Kant, calls 'radical evil'. 57 'Radical evil' amounts to violence in situations where acting violently is simply not deviant. Nino observes that "the kind of collective behaviour that leads to radical evil would not have materialized unless carried out with a high degree of conviction on the part of those who participated in it". ${ }^{58}$ When this conviction is broadly shared, it loses its deviance no matter how pronounced its ugliness. Thus the extremists may see the international penal process as the consequence of their loss of political and military authority in Rwanda and not so much, as a process aimed specifically at their push to homogenise Rwanda and the resulting

\footnotetext{
${ }^{55}$ Howland and Calathes, supra note 22, p. 153.

${ }^{56}$ See UN Doc. S/PV. 3453 (1994) supra note 3.

${ }^{57}$ C. S. Nino, Radical Evil on Trial (Yale University Press, New Haven, 1996) vii (“ '[R]adical evil' [refers to] offences against human dignity so widespread, persistent, and organized that normal moral assessment seems inappropriate.”).

${ }^{58}$ Ibid, ix.
} 
atrocities. On the hand, the Tutsis are more focused on the national trials that will send the guilty to the gallows, not some ritzy international trial that will send the guilty to Europe.

Although the ICTR has a multi-million dollar budget, by late 2000, The ICTR had 53 indictees, 45 of who were in $\operatorname{custody}^{59}$ and the Rwandan prisons have some 125,000 individuals in custody over the genocide. The ICTR had completed only 4 trials, while the work on the 48 other cases was still underway. The fact though is that between 75,000 to 150,000 possible defendants spread throughout Rwanda and in neighbouring countries as refugees will never see the inside of a courtroom. ${ }^{60}$ What about them? Do they get the message that their actions were wrong and atrocious? For some yes, for most unlikely. Journalist P. Gourevitch asks and then eerily concludes: "[W]hat if...murder and rape become the rule?"61 "During the genocide, the work of the killers was not regarded as a crime in Rwanda; it was effectively the law of the land...."62 The ICTR relied on the actor-oriented approach in which it is easy to see who should be apprehended, arraigned into court, adjudicated and eventually punished. ${ }^{63}$ This objective tended not to build dynamism and dialectics into the ICTR's vision on not only prosecuting the guilty, but also addressing impunity. The ICTR sought to depict and regulate an event where certain acts are proscribed. The rest was left open.

\footnotetext{
${ }^{59}$ This figure is as of 31 October 2000. Of the 45 in custody, 41 are held at the ICTR's detention facility at Arusha, and three others are awaiting transfer from other parts of the world. See ICTR Press Briefing, supra note 50.

${ }^{60}$ Jefremovas, supra note 21.

${ }^{61}$ Gourevitch, supra note 8, p. 34.

${ }^{62}$ Ibid, p. 123.

${ }^{63}$ The mathematics of the process are ridiculous when you consider the number of indictees to the overall figure of possible defendants.
} 


\title{
Restorative Justice: Beyond a Simplistic Bipolar Leitmotiv
}

Analysing the negative implications of criminal trials in the reconstruction of postgenocide Rwandan society, Professor M. Drumbl astutely notes that:

\begin{abstract}
"Trials create a bipolar leitmotiv of the postgenocidal society, which is binarily deconstructed into the 'guilty' and the 'innocent'. This deconstruction runs the risk of oversimplifying history by negating the importance of collective wrongdoing, acquiescent complicity, and the embeddedness of 'radical evil'. By treating genocidal violence as an individualised, pathological, and deviant transgression of social propriety, the criminal justice system may do the dualist postgenocidal society a disservice by blanketing and perpetuating the structural nature of this violence to the detriment of survivors and future generations. Blaming occurrences of radical evil entirely on the existence of some evil people obscures the fact that so many people, to varying degrees of complicity, are required for 'radical evil' to operate publicly on a macro level." 64
\end{abstract}

The more holistic perspective of restorative justice may actually help a society manage multiple goals because it identifies restoration - not deterrence, incapacitation, rehabilitation, or retribution - as the overarching goal of criminal justice. A restorative approach seems needed in all societies that have suffered massive and collective victimisation. ${ }^{65}$ There had to be an effort to identify that there are other units, individuals or groups that should be the target of efforts to restore order to the badly fractured Rwandan society. Backing a remedy designed to socialise individuals, the ICTR simply envisioned a society disintegrated into an amoral Hobbesian war of all against all, rather than into rival moral communities. Deftly noted by Dennis Wrong, for group-level conflict to occur, the individual group members must already "have been socialised to...correctly gauge the expectations of others, internalise at least some norms, and possess selves sensitive to the appraisal of others". ${ }^{66}$ The familiar lack of

\footnotetext{
${ }^{64}$ Drumbl, 'From Guilt to Shame', supra note 12, pp. 1324-1325.

${ }^{65}$ Howland and Calathes, supra note 22, p. 156.

${ }^{66}$ D. H. Wrong, The Problem of Order: What Unites and Divides Society (1994) 182. For instance, in both Nazi Germany and Rwanda in the 1990s, a strong tradition of obedience to authority prevailed. See G. M. Gerhart, 'Recent Books on International Relations: Africa', Foreign Affairs, May-June 1996, at
} 
remorse shown for acts that if committed against a member of one's own group would draw heavy censure, signals a disjunction between groups' values and norms.

The ICTR's seeming view that applying individual level justice would promote social order was bound to fail if it was the only tool envisaged. Individual level punishments can only affect a permanent change if the cause of the deviant behaviour resides solely with the individual. ${ }^{67}$ In Rwanda, however, it is impossible to conclude that the causes of deviance reside with the individual. As the ICTR was focusing its attention on individual deviants, it was presenting the world, and the Rwandans, with the image of a person who needs correcting through punishment instead of a social system, structurally stratified by ethnic rift that needs reorganisation. The Tribunal while an important instrument by which those responsible for the genocide are distinguished from moderate Hutus, needed to be nonetheless be alive to the destabilising effect being posed by Hutu extremists, many of who are not in custody, and are unlikely to ever face prosecution.

While the prosecution of former leaders is an essential ingredient for reconciliation at the political level, there has to be a corresponding transformation of values among the Rwandan people who have been subjected to decades of incitement to ethnic hatred and violence, whether as victim or as obedient perpetrator. The Tutsi must absolve the Hutu of indefinite collective responsibility for the genocide while also having a legitimate means of vindicating their suffering through a 'collective catharsis'. The ICTR in concert with the Rwanda national trials can play a decisive role in this respect. Structures cannot be juridical persons with intentions and capabilities. They cannot Out the Honest Pessimist' Financial Times (London), 13 January 1996, xvi. 
distinguish between right and wrong. While structures cannot be put on trial, they can be changed through rehabilitation, by focusing on them as the primary root of the problem as well as the indictees of the tribunal.

Attention needed be paid to how reconciliation could be facilitated in post-genocide Rwanda. Adopting a restorative approach seemed part of the answer. The restorative school of criminal justice demonstrates the importance of behavioural, material, emotional, and cognitive outcomes for victims, offenders, and societal members. ${ }^{68}$ Success in sanctioning is measured by the degree of reparation for the victims and their participation, or better yet their ownership, in the process. It also includes the recognition of the offenders of wrongdoing and their level of empathy with victims. It is further measured by the development of a shared perspective in society that offenders have been denounced and held accountable in a fair process. The Rwandan courts largely lacked credibility (and still do) with the group of perpetrators being prosecuted by an overwhelmingly Tutsi government, being overwhelmingly Hutu. Ethnic stratification is replayed as basically, the Tutsis are prosecuting the Hutus, the victors are entombing their victory through judicial process. The Rwandan national trials stood to gain by closer, formal cooperation between the national and international process, to alleviate the credibility problem.

While the Rwandan courts received mixed, and to a degree improving, reviews, many of the first trials were considered a disaster from a due process perspective. Most of the more than 125,000 detainees were arbitrarily arrested and have been detained for long

\footnotetext{
${ }^{67}$ G. R. Newman, The Punishment Response (Lippincott, Philadelphia, 1978).

${ }^{68}$ See B. S Alper and L. T. Nichols, Beyond the Courtroom (Lexington Books, Lexington, MA, 1981).
} 
periods without trial. ${ }^{69}$ To many in Rwanda, this process negatively colours their impression of the Rwandan government and its ability to fairly treat those accused of genocide. The Rwandan trials will not help achieve reconciliation if they are considered unfair or if they are removed from the population. ${ }^{70}$ Rwanda itself warned when advocating for the creation of a tribunal with international participation of 'victor's justice' if it organised the trials on its own. ${ }^{71}$

It would seem the case in Rwanda, that lasting reconciliation requires assigning individual responsibility for the atrocities, while it is imperative that trials of those accused take place, clearly, the most resonant of such trials will be those in Rwanda, organised and accomplished by the Rwandan people, so that individual responsibility is an internal, rather than an external designation. ${ }^{72}$ It follows that the high profile of the ICTR, was overshadowing and stealing the 'thunder' from the national trials rather than complementing them. The ICTR had just about all the 'big fish' while the rest were left to the Rwandan national courts.

The major reason why the international and national justice systems were failing to respond adequately to the Rwandan situation is that they inadequately focused on the crimes by defining them only as law breaking. The concentration is then solely on the

\footnotetext{
${ }^{69}$ For an interesting history of the Rwandan government's attempt to respond to the genocide and mass killings with its justice system, see Schabas, supra note 45, p. 523.

${ }^{70}$ Although the understanding of a community's perception of law and legal process is underdeveloped, especially in a place like Rwanda, fairness and morality are important. See, eg, P. H. Robinson and J. M. Darley, Justice, Liability, and Blame: Community Views and the Criminal Law (Westview Press, Boulder, CO, 1995).

${ }^{71}$ Letter Dated 28 September 1994 from the Permanent Representative of Rwanda to the United Nations Addressed to the President of the Security Council, supra note 3.

${ }^{72}$ The war crimes trials taking place in Ethiopia provide an example of a process that may bring about such internal recognition. See Stuart H Deming, 'War Crimes and International Criminal Law', 28 Akron Law Review (1995) p. 424; 'Ethiopia Ex-Rulers Go on Trial', New York Times, 14 December 1994, A8.
} 
resulting adversarial relationship between government (or Tribunal) and the criminal offender. This existing pattern of thinking fails to address, or even recognise, the other dimensions involved. A human rights crime is not merely an offence against the State. Likewise, justice is more than punishment and incapacitation. There are larger issues at play, notably the issue of standards and norms. Despite the public nature of the genocidal violence, there is very little generally accepted truth in Rwanda as to what exactly happened from April to July $1994 .^{73}$ In this regard, a truth commission could help establish an historical narrative of what happened as well as why it happened; ${ }^{74}$ after this record is established, Rwandan society then could be better positioned to render a moral evaluation of the genocide. ${ }^{75}$

In a deeply divided society, arguably the only type of society likely to produce the types of crimes for which the ICTR was established, criminal prosecutions do not necessarily have a conciliatory effect. Rather, they manifest and exacerbate division if seen as some sort of panacea. This follows in part because those who would occupy the dock are

\footnotetext{
${ }^{73}$ But see Neier, supra note 27, p. 43 (suggesting that because of public nature of violence, truth process in Rwanda would fail to make important contribution). Neier is correct in pointing out that the fact that the genocide was committed so publicly means many people knew about it. But reports from Rwanda reveal that there is little, if any, shared understanding as to the wrongfulness of the violence. There is an important difference between the genocide generally being known and the wrong of the genocide meaningfully being acknowledged.

${ }^{74}$ See J. Zalaquett, 'Balancing Ethical Imperatives and Political Constraints: The Dilemma of New Democracies Confronting Past Human Rights Violations' 43 Hastings Law Journal (1992) p. 1431 (concluding that truth commissions "are most useful where broad sectors of society do not... acknowledge critical facts").

${ }^{75}$ In 1994, a commission of experts, established pursuant to Security Council Resolution 935, prepared a preliminary report on violations of international humanitarian law in Rwanda. See Letter from B. Boutros-Ghali, Secretary-General, United Nations, to the President of the Security Council, Annex: Final Report of the Commission of Experts Established Pursuant to Security Council Resolution 935 (1994), UN Doc S/1994/1405 (9 December 1994). The report of this commission of experts was a first step in the formation of the ICTR. The United Nations High Commissioner for Human Rights established a "special investigations unit... to gather evidence that might otherwise have been lost or destroyed". Report of the High Commissioner for Human Rights on the Activities of the Human Rights Field Operation in Rwanda Submitted Pursuant to General Assembly Resolution 50/200, UN Doc E/CN.4/1996/111 (1996) para. 5.
} 
inevitably and widely seen as symbolic representatives of their group. ${ }^{76}$ The association is even greater in cases involving 'big fish'. As the prosecution declared at the opening of the Adolf Eichmann trial, "It is not an individual that is in the dock (,)...but antiSemitism throughout history". ${ }^{77}$ Given its metaphorical significance, one can hardly expect the ICTR to ameliorate collective guilt. On the contrary, it may actually revive and inflame antagonistic sentiment. ${ }^{78}$

The overall purpose of restorative justice is the reintegration of victims and offenders who have resolved their conflicts into safe communities. ${ }^{79}$ This purpose can only be achieved when multiple parties (victims, offenders, communities, governments) pursue multiple goals (redress, fairness, healing, and rehabilitation). There have been killings of a number of unarmed civilians, some by members of the Rwandan security forces, others by armed opposition groups (the interahamwe militia), others by unidentified assailants. Members of local defence forces have been responsible for killings and other abuses, especially in the northwest of Rwanda, sometimes in conjunction with Rwanda Patriotic Army (RPA) soldiers. ${ }^{80}$ This reinforced the need to pursue multiple goals within the framework of objectives of the international justice system otherwise, the international community would have to find an alternative way to address human rights

\footnotetext{
${ }^{76}$ See C. Simic, 'Unfashionable Victims' London Review of Books, 31 July 1997, p. 12 (stating that R. Karadzic and R. Mladic "are taken as embodiments of the soul of their people").

${ }^{77}$ H. Arendt, Eichmann in Jerusalem: A Report on the Banality of Evil (Penguin Books, New York, 1963) p. 16.

${ }^{78}$ See T. Rosenberg, 'Defending the Indefensible', New York Times Magazine, 19 April 1998, pp. 46,56 (remarking on the "near-universal belief among Serbs that the tribunal is an anti-Serb instrument").

${ }^{79}$ See D. Van Ness and K. H. Strong, Restoring Justice (Anderson, Cincinnati, 1997).

${ }^{80}$ Amnesty International Report, infra note, 89. For a positive development, see T. Wanyonyi, 'Peace May Be Crucial But So Is Justice to All', Daily Nation (Kenya), 4 January 2001, Commentary, noting the UN Prosecutor's announcement that the members of the RPA (formerly the rebel RPF) will be investigated for alleged killings during the genocide period when the RPF launches a major military offensive that brought the Tutsis to power.
} 
abuses by an overzealous Tutsi-dominated army, clearly having personal and official business weaved into a single tapestry.

A presupposition of the ICTR was that formal mechanisms are integral to uphold group life and to stem deviant behaviour. ${ }^{81}$ Reminiscent of pre-sociological thought, this view overlooked the "complex network of social ties which spontaneously creates a normative order that exists independently of (legal institutions)" ${ }^{82}$ Cooperation and understanding by the Rwandan society is a sine qua non of long term ethnocentric hate control and societal restructuring. Although the Tutsis are now in control they cannot hold it without the goodwill of the Hutu segment. ${ }^{83}$ For lasting peace, N. Mandela proclaimed, "we do not rely on laws, we rely purely on persuasion". ${ }^{84}$ Where society

\footnotetext{
${ }^{81}$ K. Annan, Secretary General of the United Nations, stated that all peoples of the world should have basic human rights and that the basis of law ensures those rights. K. Annan, 'Advocating for an International Criminal Court' 21 Fordham International Law Journal (1997) p. 363. He thus advocates a formal court to administer that law. See ibid, 365.

${ }^{82}$ Wrong, supra note 64, p. 170 . 'It is the social process in group life that creates and upholds the rules, not the rules that create and uphold group life.' Ibid 49; see generally R. J. Sampson et al, 'Neighbourhoods and Violent Crime: A Multilevel Study of Collective Efficacy', Science, 15 August 1997, pp. 918-19, 923 (finding that 'collective efficacy,' meaning informal social control, cohesion, and trust, remains a significant predictor of violent crime).

${ }^{83}$ Starting in 1999, the Rwandan government implemented a national policy which required many people to abandon their homes in order to be housed in new 'villages' or settlements known locally as imidugudu. In the northwestern préfectures of Gisenyi and Ruhengeri, in particular, families were forced to move, sometimes under threat and intimidation. Some were made to destroy their old homes but were not provided with assistance to construct new ones. The policy was officially designed to improve security and ensure greater facilities and infrastructure, but by the end of 1999 living conditions for hundreds of thousands - especially in the northwest - remained very poor. Amnesty International Report, infra note 89 . Such structural strategies are definitely wrong, at least the aggressive and abrasive stance by the government. In implementation. Arbitrary arrests and detentions were reported. Unsubstantiated accusations of participation in the genocide were frequently used as a way of settling scores or to prevent property owners from reclaiming illegally occupied property. Now this falls in the structure-oriented perspective. It catches types of evil, repression (political) and exploitation (economic). The evils here are clear but without presupposing evil actors. See I. Jesudasan, A Gandhian Theology of Liberation (1987) p. 287 (referring to Gandhi's insight into the need for any long-term government to have the consent of the governed).

${ }^{84}$ P. Waldmeir, Anatomy of a Miracle: The End of Apartheid and the Birth of the New South Africa (W. W. Norton, New York, 1997) p. 261.
} 
depends instead on law, Gandhi concluded that "law ceases to be law, and society ceases to be society". ${ }^{85}$

The inter-ethnic hatred in Rwanda is a 'deep-culture', a socio-cultural code embedded in the collective subconscious of the group entities, defining for that collective that it is normal/natural to adopt a 'no-holds-barred' approach to gaining ethnical supremacy and preserving the resulting ethnic hegemony. Being subconscious, there is not much individual awareness of deeply rooted international legal standards steering the rest of the world, the result of almost a century of brainwashing. With a deep structure of hatred and animosity rooted in a culture, the ICTR was running against something very solid indeed. A signal challenge to the ICTR is the core precept of Satyagraha, that the ends pre-exist in the means. In Gandhi's words, "the belief that there is no connection between the means and the end is a great mistake... The means may be likened to a seed, the end to a tree; and there is just the same inviolable connection between the means and the end as there is between the seed and the tree." 86

\section{Waking up to Reality: Trends and Transformations}

\section{Developments on the ICTR Front}

Killings in Rwanda rose in the period after the ICTR's founding. ${ }^{87}$ Although currently the number of killings inside Rwanda has decreased compared to the rather bloody 1998-2000 period, killings of unarmed civilians and 'disappearances' were still reported

\footnotetext{
${ }^{85}$ V. S. Hegde, 'The Practice of Law and Gandhi' in New Dimensions and Perspectives in V. T. Patil (ed) Gandhism (Inter-India Publications, New Delhi, 1989) p. 424.

${ }^{86}$ D. Dalton, Mahatma Gandhi: Non-violent Power in Action (Columbia University Press, New York, 1993) p. 9.

${ }^{87}$ The genocidal militia continued the killing. The territory in which it is operating and the numbers of victims have rose steadily in 1997. In response, killing by Rwandan government forces also increased. See US Department of State, Rwanda Country Report on Human Rights Practices (1997).
} 
throughout 2001-2002. As government troops regained control of the northwest, the armed conflict abated and the level of violence decreased. However, the situation remained tense and the peace fragile. In many respects, the armed conflict during which thousands of civilians had been killed in Rwanda in 1998 continued over the border in the Democratic Republic of Congo (DRC). The presence of armed groups continued to be reported sporadically in Rwanda near the DRC border and the Rwandan Patriotic Army (RPA) (formerly the rebel RPF) carried out military operations in this area. ${ }^{88}$

The ICTR's existence and presence in Eastern Africa was seemingly doing little to deter extremist Hutus in neighbouring countries from waging bloody guerrilla-style excursions into Rwanda. Thousands of unarmed civilians were killed across the border, in the Democratic Republic of the Congo (DRC), in an armed conflict involving several governments, including Rwanda, as well as various armed opposition groups, including Rwandan interahamwe militia and soldiers of the former Rwandan armed forces. The Rwandan government offered support to the rebel Congolese Rally for democracy (RCD) part of the deal being permission to conduct military operations in Congolese territory against Hutu extremists. The overzealous Rwandan government troops were not averse to conducting ruthless military operations around refugee camps ${ }^{89}$ reinforcing its apparent commitment to consolidating a national ethnocracy. The same zeal was reflected by the Hutu extremists keen to wrestle back the reins of power from the Tutsi dominated government.

\footnotetext{
${ }^{88}$ Amnesty International Report, infra note 89.

${ }_{89}$ Amnesty International, Amnesty International Report: 2000 (2000), http://www.web.amnesty.org/web/ar 2000.nsf/, visited 10 December 2003.
} 
The ICTR was criticized (and rightly so) for not achieving its mandate swiftly enough. Although the ICTR has a multi-million dollar budget, by early 2000, six years after its establishment it had completed only four trials, while the work on the 48 other cases was still underway. One of the reasons for the delays, however, is that the ICTR is a nascent criminal court. At the start of 2000 however the ICTR shook of the lethargy that characterized its earlier years of existence. The ICTR made significant progress on numerous fronts in 2000. In addition to securing new convictions and concluding several appeals, the Tribunal significantly improved its relationship with the Rwandan government. The Tribunal began the year under a cloud of severely strained relations with the Rwandan government in the aftermath of the Appeals Chamber's 1999 decision to dismiss charges against J. Barayagwiza. ${ }^{90}$ However, in March 2000, the Appeals Chamber quashed the earlier ruling and reinstated charges against Barayagwiza, which the Rwandan government saluted as a "victory for victims." 91

Keenly aware that an international justice process that fails to deter individuals with reason enough to value their lives and freedom can only be regarded as meaningless, the ICTR took numerous steps to repair and improve its relationships with the Rwandan government and citizens. In 2000, ICTR judges for the first time agreed to requests by the Rwandan government to personally visit crime scenes. ${ }^{92}$ More significantly, the ICTR's chief prosecutor, C. Ponte, announced that she would ask the Trial Chambers to hold future hearings in Rwanda, and that in the future "it might even be possible to ...

\footnotetext{
${ }^{90}$ For a summary of this November 3, 1999 decision and reactions to it, see M. Shenk et al, 'International Criminal Tribunal for the Former Yugoslavia and for Rwanda', 34 International Law News (2000) p. 683.

91 See Coalition for International Justice, 'Barayagwiza to Face Trial', 31 March 2000, http://www.cij.org/content.html, visited 24 February 2001.

92 See Coalition for International Justice, 'ICTR Judges to Visit Crime Scenes', 16 August 2000, http://www.cij.org/content.html, visited 24 February 2001. In response, M. Ngoga, Rwanda's
} 
[move] the entire Tribunal to Kigali." ${ }^{93}$ Furthermore, in September 2000 the ICTR opened an information and outreach centre in Kigali, which will house a public information area, documents repository and legal library, and manage the Victims Assistance Programme. ${ }^{94}$

Fifteen months later, relations between the ICTR and the Rwandan government took a turn for the worse. The first sign of trouble occurred in January 2002 when two key Rwandan genocide survivors' groups not only suspended their cooperation with the ICTR but also called on the Rwandan Government to do the same. ${ }^{95}$ Three months later in March 2002, a proposal for a joint ICTR/government task force fell on its face due to the "inability to agree on certain fundamental points, beyond compromise, regarding the proposed commission's terms of reference." 96

It would appear that this was a politically motivated action based on the Prosecutor's investigation of crimes allegedly committed by the Rwanda Patriotic Army soldiers

representative to the ICTR, stated that the decision by the ICTR indicated that "many things have been put right as far as the workings of the Tribunal and its relationship with Rwanda ..." Ibid.

${ }^{93}$ See Prosecutor Seeks to Move ICTR Hearings on Genocide to Rwanda, Xinhua, 21 November 2000. Currently, all trial proceedings are held at the seat of the court in Arusha, Tanzania. Ms. Del Ponte further stated that such a move was now possible because "relations with the government has [sic] now reached a stage where proper guarantees can be given and relied upon for the holding of ICTR trials in Rwanda itself," and that such a move was necessary because the ICTR " must make [its] work more relevant to the people of Rwanda." Ibid.

94 See ICTR Press Release, 'ICTR Information Centre Opens in Kigali' 25 September 2000, http://www.ictr.org/ENGLISH/PRESSREL/2000/241.htm, visited 24 December 2000. The Victims Assistance Programme will provide "counselling for victims who are witnesses or potential witnesses before the tribunal." Ibid.

${ }^{95}$ M. Kimani, 'Rwandan Genocide Survivor Groups Suspend Co-Operation With ICTR', Internews, 28 January 2002, http:// www.internews.org/activities/ICTR_reports/ICTRnewsJan02.html\#1028a, visited on 30 August 2003. It was to take more than a year before the cooperation was resumed.

${ }^{96}$ Press Release, International Criminal Tribunal for Rwanda, 'Registrar Decides to Withdraw his Proposal to Establish a Joint Commission to Investigate Allegations of Mistreatment of Witnesses from Rwanda' 17 April 2002, http://www.ictr.org/wwwroot/default.htm, visited 20 August 2003; S. Kaliisa; 'ICTR Registrar Withdraws Controversial Taskforce', Internews, 18 April 2002, http:// www.internews.org/activities/ICTR_reports/ICTRnewsApr02.html, visited 30 August 2002. 
affiliated with the current government. ${ }^{97}$ The Prosecutor later brought the dispute before the UN Security Council, noting that the attitude of the Government toward the tribunal had "hardened" because the ICTR began investigations of individuals with connections to the current Rwandan army. ${ }^{98}$ The Rwandan government soon backed away from its contentious policies but not after a sweetener was thrown its way, a freeze on investigations of RPF, yet another blow to the overall bid for reconciliation. Later in 2002, the frosty relations thawed when Chief Prosecutor, C. Ponte, announced her intention to transfer forty suspects to Rwanda and other national jurisdictions for prosecutions bringing to fruition a promise made almost two years earlier. ${ }^{99}$ In addition, the Security Council granted the ICTR's request to create a pool of eighteen ad litem judges to supplement the work of the nine trial judges already sitting on the ICTR with an aim of increased speed and efficiency after enacting similar reforms for the ICTY. ${ }^{100}$

The improved relations between the ICTR and the Rwandan government may facilitate what many believe is necessary to the ICTR's legitimacy - investigation and, if appropriate, indictment and prosecution of persons from the largely Tutsi Rwandan

\footnotetext{
${ }^{97}$ Letter from K. Roth, Executive Director, Human Rights Watch, to UN Security Council Members, 25 October 2002, at http:// hrw.org/press/2002/10/noncooperation-Itr.htm, visited 5 March 2003.

${ }^{98}$ S. Kaliisa, 'ICTR Responds to Inefficiency Claims by Rwandan Government', Internews, 16 August 2002, http:// www.internews.org/activities/ICTR_reports/ICTRnewsJul02.html, visited 5 December 2002; see also Letter from K. Roth, Executive Director, Human Rights Watch, to US Ambassador J. Negroponte, President of UN Security Council 9 August 2002, http://hrw.org/press/2002/rwandaItr0809.htm, visited 14 January 2003.

${ }^{99}$ See Seventh Annual Report of the International Criminal Tribunal for the Prosecution of Persons Responsible for Genocide and Other Serious Violations of International Humanitarian Law Committed in the Territory of Rwanda and Rwandan Citizens Responsible for Genocide and Other Such Violations Committed in the Territory of Neighbouring States between 1 January and 31 December 1994: Note by the Secretary General, UN GAOR 57th Sess., Agenda Item 46, UN Doc. A/57/163-S/2002/733 (2002), para. 3; S. Chhatbar, 'ICTR Can Now Transfer Cases to National Courts', Internews, 8 July 2002, http://www.internews.org/activities/ICTR_reports/ICTRnewsJul02.html, visited 20 December 2002.

${ }^{100}$ See Shenk et al, supra note 90 at p. 574; see also Press Release, International Criminal Tribunal for Rwanda, ICTR 'President Welcomes Ad Litem Judges Resolution' ICTR/INFO-9-3-12, 15 August 2002, http:// www.ictr.org/wwwroot/default.htm, visited 10 December 2002; S. Kaliisa, 'UN Security Council Approves 18 Ad Litem Judges for Rwanda Tribunal', Internews, 15 August 2002, http://www.internews.org/activities/ICTR_reports/ICTRnewsAug02.html, visited 30 October 2002.
} 
Patriotic Front (RPF). ${ }^{101}$ The RPF is the rebel movement that seized power after the massacres in Rwanda, and remains in power as Rwanda's current government. The failure of the ICTR to indict RPF members exposed the Tribunal to criticisms of being a "victor's tribunal." 102 The ICTR chief prosecutor not only intends to investigate RPF members, but initially publicly secured the cooperation of the Rwandan government in this endeavour. ${ }^{103}$

On the trial front, between 1 July 2001 and 30 June 2002, 11 accused persons were arrested, and the Prosecutions Division submitted 14 new indictments for confirmation, all of which were confirmed. Of the 60 persons already arrested, 8 were sentenced, 1 was acquitted, 22 are involved in ongoing trials and 29 are in custody awaiting the commencement of their trials". ${ }^{104}$ In the same period, the Tribunal was actively engaged in trials. Nine trials of 22 accused persons were in progress before three Trial Chambers, with three judgments in respect of four accused being rendered the following year. ${ }^{105} \mathrm{By}$ the close of 2002, 81 individuals had been indicted by the ICTR, with 61 in custody and twenty at large. ${ }^{106}$ Eight people had been convicted by the ICTR, and the Appeals

\footnotetext{
${ }^{101}$ See 'Missing', The Economist, 23 December 2000 (US Edition).

102 See C. M. Carroll, 'An Assessment of the Role and Effectiveness of the International Criminal Tribunal for Rwanda and the Rwandan National Justice System in Dealing with the Mass Atrocities of 1994' 18 Boston University International Law Journal (2000) p. 163. Reasons cited in defence of the past policy to limit indictments to Hutus include the desirability of "indicting and prosecuting the most serious violators first," and the desire to "maintain good relations with the current Tutsi government in order to facilitate its investigation of international humanitarian law violations in Rwanda." However, it has also been established that there is "overwhelming evidence to prove that Tutsis [have] committed ... serious violations of international humanitarian law" during the 1994 massacres. Ibid.

${ }^{103}$ See Coalition for International Justice, 'Del Ponte Meets with Kagame; ICTR Investigation of RPF Addressed', 14 December 2000, http:// www.cij.org/content.html, visited 24 February 2001.

104 International Criminal Tribunal for Rwanda, 'Achievements of the ICTR', 2 March 2002, $\langle$ http://www.ictr.org/ENGLISH/geninfo/achieve.htm〉, visited 2 March 2002.

${ }^{105}$ Ibid. para. 2.

106 'International Criminal Tribunal in Rwanda, ICTR Detainees-Status on 28 February 2003', http://www.ictr.org/wwwroot/default.htm, visited 10 June 2003 [hereinafter ICTR Detainees].
} 
Chamber upheld seven of those convictions. ${ }^{107}$ The 2001 acquittal of one individual was also upheld on appeal, and one appeal is currently pending. ${ }^{108}$ Trials are ongoing for twenty-two individuals. ${ }^{109}$ By the end of January 2004, the ICTR had rendered 15 judgments involving 21 accused. This brings the total number of judgments during the ICTR's second mandate to nine involving 14 accused. This represents a two-fold increase in trials compared to its first mandate (1995-1999). The Prosecutor also revised the ICTR's future investigation programme from the originally estimated number of 136 new suspects to 14 new individuals, together with 10 ongoing investigations. The resulting 24 new indictments, which the Prosecutor intends to submit for confirmation by the end of 2004, will conclude the investigation programme. ${ }^{110}$

More importantly, the Prosecutor identified 40 suspects whose prosecution was to be deferred to national jurisdictions for trial. Fifteen of these suspects were in countries that have adopted the principle of universal jurisdiction and could be tried in these countries. The cases of 25 other suspects who did not occupy high positions of responsibility could be transferred to the Rwandan authorities. This move is important as there is now a working strategy between the international and national penal processes. Instead of the initial position of the ICTR dealing solely with individual criminals and not with a culture of impunity, there is now recognition that synergy between the international and domestic penal processes will give the latter legitimacy and facilitate restorative justice initiatives. The structural distance of the ICTR from the

\footnotetext{
${ }^{107}$ Ibid.

${ }^{108}$ Ibid.

109 Ibid.

${ }^{110}$ Ibid, para. 9.
} 
Rwandan social process is being bridged and increasingly making the work of the ICTR's relevant to the Rwandan populace.

\section{Developments on the National Front}

After the 1994 genocide, the Rwandan government did not have the judicial capacity or the legislation to deal with crimes of genocide. In 1996, therefore, the government adopted the Organic Law on the Organization of Prosecutions for Offences Constituting the Crimes of Genocide or Crimes Against Humanity Committed since 1 October 1990 ('Genocide Law') and created a special judicial chamber to try the genocide cases an effort to hold individuals who will not be prosecuted by the ICTR responsible for international humanitarian law violations. The law created 13 specialised chambers within the court structure to deal with cases flowing from the genocide. ${ }^{111}$ The Rwandan judicial system, however, still is not capable of enforcing the Constitution and other laws, honouring the rights of the accused, or processing cases within a reasonable time frame. $^{112}$

Although the status of the special chamber created to hear genocide cases and the judicial system as a whole has improved since 1994, the judiciary continues to suffer from inadequate resources, inefficiency, corruption, and executive influence. ${ }^{113}$ As few individuals with legal training were left in the country after the 1994 conflict, the

\footnotetext{
${ }^{111}$ M. A. Drumbl, 'Rule of Law Amid Lawlessness: Counselling the Accused in Rwanda's Domestic Genocide Trials', 29 Columbia Human Rights Law Review (1998) pp. 593-94.

${ }^{112}$ See See See US Dept. of State, 1999 Country Reports on Human Rights Practices, Rwanda, (2000) Introduction, § 1(d), www.state.gov/www/global/human_rights/1999_hrp_report/rwanda.html, visited 14 October 2000.

${ }^{113} \mathrm{Ibid}, \S 1(\mathrm{e})$.
} 
country has struggled to find replacements for these key positions. ${ }^{114}$ Many of the judges are subject to threats of death or bodily injury and occasional influence by the government. $^{115}$

The shortage of prosecutors and defence attorneys also has made it difficult to establish fair trials. Those individuals who do serve these functions are also susceptible to threats. Accusations have been made that prosecutors or defence counsels who readily support the rights of the accused will themselves become susceptible to charges of genocide. ${ }^{116}$ The accused are entitled to a defence attorney under the 1996 genocide law, but the state will not provide one if the accused is indigent.

Many people who are incarcerated have not yet had charges brought against them. With the help of foreign assistance, case files were created for over fifty percent of the detainees in $1998 .{ }^{117}$ Periodically, the government releases thousands of suspects for which the prosecution has no case files. Though upwards of 15,000 prisoners have confessed, few of them have been processed because there are not enough officials to handle this volume of cases. ${ }^{118}$ The situation is even worse for those who are awaiting judgment by the Rwandan judicial system. As of February 2000, 130,000 individuals were awaiting trial on genocide charges. They were incarcerated in deplorable conditions: in prisons and military and communal detention centres that have an official

\footnotetext{
${ }^{114}$ See Institute for Peace, Special Report, Rwanda: Accountability for War Crimes and Genocide (1994); Amnesty International, 'Rwanda: Unfair Trials: Justice Denied', 8 April 1997, § 1, http://www.amnesty.org/ailib/aipub/1997/AFR/14700897.htm, visited 10 March 2000.

${ }^{115}$ See 1999 State Department Human Rights Report, supra note 112, Introduction.

${ }^{116}$ See Rwanda: Unfair Trials: Justice Denied, supra note 114, § 4(c).

${ }^{117}$ See 1999 State Department Human Rights Report, supra note 112, §1(d).

${ }^{118} \mathrm{Ibid}, \S 1(\mathrm{e})$.
} 
capacity of $30,000 .{ }^{119}$ A number of these individuals have been detained since $1994 .{ }^{120}$ Although Rwandan law prohibits arbitrary arrest and detention, unlawful detentions and arrests are common. ${ }^{121}$ Despite the fact that Rwandan law prohibits torture, NGOs report that the Rwandan authorities have tortured detainees. ${ }^{122}$ This only serves to reinforce the hard feelings between the two groups, as it appears to be some kind of victors justice, that may even turn the pacific sentiments held by moderate Hutus into bitterness. Specifically referring to the Rwandan proceedings, M. Minow concludes that "[r]ather than ending the cycles of revenge, the trials themselves were revenge". ${ }^{123}$ No doubt the Hutu extremists will be itching for a chance to pay back the Tutsis in their own coin in the future.

In the past seven years since the passage of the domestic Genocide Law, over 5,000 defendants have been processed by the specialized chambers ${ }^{124}$ however this though extremely impressive is inadequate. Senior judicial officials of the ICTR have noted that at the current processing speed it would likely take "400 years to try the 120,000 people" in Rwandan prisons. ${ }^{125}$ In view of the slow pace of trials and the citizenry's continued cries for justice, in July 1997, the government of Rwanda began contemplating alternatives to dealing with the huge numbers of detainees, the slow pace of trials and the lack of national reconciliation. It established a National Unity and

\footnotetext{
${ }^{119}$ In 1999 alone, at least 1,100 died in custody: most from curable illnesses but some also from abuse. See 1999 State Department Human Rights Report, supra note 150, § 1(c). See also 'Rwanda to Execute 33 in Public for Genocide', Agence France-Presse, 22 April 1998, 1998 WL 2266677.

${ }^{120}$ See 1999 State Department Human Rights Report on Rwanda, supra note 99, § 1(d).

${ }^{121}$ See Ibid. $\$$ 1(d); Amnesty International Report 1999: Rwanda (1999), at www.amnesty.org/ailib/aireport/ar99/afr47.htm.

${ }^{122}$ See 1999 State Department Human Rights Report on Rwanda, supra note 112, § 1(c).

${ }^{123}$ Minow, supra note 44, p. 124.

${ }^{124}$ Pernille Ironside, 'Rwadan Gacaca: Seeking Alternative Means to Justice, Peace and Reconciliation' 5 New York International Law Review (2002) pp. 37-38.
} 
Reconciliation Commission in 1999 that initiated countrywide consultations on issues of co-existence between Hutus and Tutsis. ${ }^{126}$ The Commission ultimately recommended that Rwanda adopt the traditional Gacaca system, whereby respected community elders endeavour to bring disputants together in an effort to render communal justice. ${ }^{127}$ In turn, this led to the adoption of Organic Law No. 40/2000 of 26 January 2001, setting up "Gacaca jurisdictions."128 The Gacaca courts were inaugurated in 2002. Roughly 260,000 men and women from every community were elected to preside over the courts, each of which has nineteen judges. ${ }^{129}$ Rwanda's President, Paul Kagame, urged all Rwandans to participate in the Gacaca process, which began widespread implementation in June 2002. ${ }^{130}$ The participatory justice system of "gacaca," a traditional mechanism for settling village quarrels, to deal with lower level offenders at a community level is an important move in the restorative justice paradigm. Kent Roach's review of public inquiries ${ }^{131}$ reveals that their unique institutional features allow them to hold organisations and society accountable in ways that courts cannot. ${ }^{132}$

\footnotetext{
${ }^{125}$ See generally B. Muna, N. Pillay \& T. Rudasingwa, 'The Rwanda tribunal and its Relationship to National trials in Rwanda', 13 American University International Law Review (1998) p, 1490.

126 'Rwanda: Reconciliation Commission Making Progress', Africa News, 27 June 2001, (reporting that the National Unity and Reconciliation Commission has established programs to bring about reconciliation between the Hutus and Tutsis).

${ }^{127}$ M. H. Morris, 'Rwandan Justice and the International Criminal Court', 5 ILSA Journal of International and Comparative Law (1999) p. 352.

${ }^{128}$ Organic Law No. 40/2000 of 26 January 200.

${ }^{129}$ M. Kimani, 'Ambassador Says United States Wants UN Tribunals to Conclude Work Soon', Internews, 8 February 2002, http:// www.internews.org/activities/ICTR_reports/ICTRnewsFeb02.html, visited 14 August 2002.

130 'Rwandan to Resurrect Traditional Justice System', Global Policy Forum, 17 June 2002, http://www.globalpolicy.org/general/2002/0617ga.htm, visited 30 July 2002; S. Kaliisa, 'Rwandan President Inaugurates "Gacaca" Justice System', Internews, 18 June 2002, http://www.internews.org/activities/ICTRreports/ICTRnewsJun02.html, visited 30 July 2003.

${ }^{131}$ K. Roach, 'Canadian Public Inquiries and Accountability' in P. C Stenning (ed) Accountability for Criminal Justice: Selected Essays (1995).

${ }^{132}$ Ibid, p. 273 (" $[\mathrm{M}]$ ost courts continue to put individuals, not organizations, on trial. They stress individual responsibility for wrongs and not the structural shortcomings of institutions, even if only organizational reform can prevent similar wrongs in the future.").
} 
The Gacaca Law preserves the basic structure of offences and the procedures for confessions and guilty pleas established by the Genocide Law, which formed the basis for domestic genocide trials. ${ }^{133}$ Specifically, it classifies detainees into one of four categories according to their alleged participation in particular crimes. "As in the Genocide Law, the Gacaca Law provides an incentive for defendants to confess and plead guilty in exchange for a reduced sentence. For both confession procedures, half of the defendant's sentence will be served in custody while the rest is commuted into community service." 134

The gacaca system could have potentially positive or negative effects on achieving accountability and reconciliation in Rwanda. On the positive side, gacaca could ease the burden on the courts and prison system by helping to quickly process the innocent and guilty. The process also could have a cathartic effect by allowing many individuals in society to discuss the genocide, participate in the creation of justice and a standard of responsibility for criminal actions, and more swiftly deal with recent traumatic events. Gacaca advocates argue that gacaca is a more efficient solution for Rwanda because rehabilitative penalties can be quickly assigned if "the moral force of the village [is used] to shame perpetrators into admitting the truth." 135 Some Rwandans, who feel that Western- style justice is not working, believe this kind of group justice will serve as a tool for reconciliation. ${ }^{136}$ For example, Rwandan Justice Minister J. Mucyo, believes that the gacaca system will lead to truth for the whole society whereas western-style

\footnotetext{
133 See Organic Law on the Organization of Prosecutions for Offences Constituting the Crime of Genocide or Crimes Against Humanity Committed Since 1 October 1990, Law No. 8/96, Rwanda Official Gazette, 30 August 1996, art. 66.

${ }^{134}$ See Ironside, supra note 124, pp. 44-45.

${ }^{135}$ See E. Neuffer, 'It Takes a Village', The New Republic, 10 April 2000, p. 114.
} 
justice only leads to a small part of the truth for the accused, the judge, and the victims. ${ }^{137}$ This view is echoed by P. Ironside who observes:

\begin{abstract}
"In the context of post-genocidal Rwanda, Gacaca may well be able to heal the deep wounds that continue to divide the country by ethnicity in a manner for which Western retributive systems are not designed. Indeed, it is unrealistic, impractical and short-sighted to rely solely on the ordinary criminal law model with all of its due process guarantees to address mass perpetration of crimes, particularly in a country whose judicial system has to be built ex nihilo and where ethnic tensions continue to run high." $" 138$
\end{abstract}

Observers however have expressed a number of concerns with the gacaca system. ${ }^{139}$ Numerous concerns arise from the fact that the Gacaca system is structured as a speedy penal justice process but lacking the requisite due process safeguards. Although the African Commission on Human \& People's Rights stated in its Dakar Declaration of 11 September 1999 that "traditional courts are not exempt from the provisions of the African Charter on Human and Peoples' Rights relating to a fair trial," ${ }^{\text {, }}$ ' the Gacaca process falls short of this and other internationally recognized standards. For instance, the Gacaca Law does not mention any entitlement of defendants to legal representation; ${ }^{141}$ the Gacaca Law does not allow defendants to present evidence during the process when the defendants are graded according to the severity of their crimes; ${ }^{142}$ and the practice of distributing cases for processing to Gacaca jurisdictions based on the

\footnotetext{
${ }^{136}$ See Report of the Situation of Human Rights in Rwanda Prepared by the Special Representative of the Commission on Human Rights Pursuant to Economic and Social Council Decision 1999/288, UN GAOR, 54th Sess., Agenda Item 116(c), UN Doc. A/54/359 (1999), paras. 147, 156.

${ }^{137}$ See Neuffer, supra note 135

${ }^{138}$ See Ironside, supra note 124, pp. 33-34.

${ }^{139}$ See 1999 Report of the Special Representative of the UNCHR, supra note 136, para. 155.

${ }^{140}$ Dakar Declaration of the African Commission on Human and Peoples' Rights, Dakar, Senegal, 11 September 1999.

${ }_{141}$ Gacaca Law, supra note 128.

${ }^{142}$ Ibid.
} 
defendant's residence before the genocide will inevitably result in unequal administration of justice. ${ }^{143}$

There are several other disadvantages to the gacaca system. As P. Ironside cautions “... many of its features resemble those of the criminal justice system but without all of the accompanying procedural safeguards, which raises concerns as to whether the new system will simply amount to criminal justice in the guise of popular justice." ${ }^{144}$ In a further sobering reflection, Ironside observes that "Notwithstanding its capacity to yield beneficial, indeed essential, results, the Gacaca system also raises a number of valid concerns. For instance, while the process may heal some wounds, it could actually reopen others and thereby exacerbate ethnic tensions. The potential also exists that the government's motives are not altogether virtuous in instituting the Gacaca system, but rather stem from the increasing rate of acquittals by the specialized chambers, which the government may wish to curb by subjecting defendants to Gacaca's community justice." ${ }^{145}$ Overall then, the process could breed the spirit of vengeance and bitterness and help continue the culture of impunity instead of prevent it. Individuals participating in these processes might fabricate stories in order to seek revenge against certain individuals, feel reluctant to hold their families and neighbours accountable, or see this not as an opportunity to seek justice, but revenge. ${ }^{146}$ If these shortcomings could be dealt with, however, gacaca could have a significant impact by helping individuals realize on a personal level that they live in a society with accountability, law, and justice. In summary, although the Rwandan justice system still has a long way to go

\footnotetext{
${ }^{143}$ Morris, supra note 9 , pp. 354-55

${ }^{144}$ See Ironside, supra note 124, p. 48.

145 Ibid, p. 50.

${ }^{146}$ See Prendergast \& Smock, supra note 111.
} 
before becoming a model of impartiality and justice, international observers have reported that it has continued to make progress since the 1994 conflict. ${ }^{147}$

The Rwandan government has taken further steps outside the traditional adversarial legal system to deal with the genocide in the past and to prevent mass atrocities in the future. In 1999 the Rwandan government established a National Human Rights Commission (NHRC) and a National Unity and Reconciliation Commission (NURC). ${ }^{148}$ The role of the NHRC is to investigate human rights violations, especially by state actors, to train Rwandan citizens about human rights, and to assist in the initiation of judicial proceedings against persons suspected of committing human rights violations. ${ }^{149}$ These initiatives are important since much of the Tutsi minority, historically dominant, lives with the phobia of its physical elimination, while the Hutu majority demands proper political representation. The 1994 genocide in Rwanda heightened the fears of the minority, creating a volatile situation in which extremist elements in both communities may destroy the fragile peace in existence. In such an environment, dissemination of the wrongfulness of the ethno-centric hatred is important in avoiding the voices of moderation being drowned out, silenced or eliminated altogether. ${ }^{150}$

\footnotetext{
${ }^{147}$ See Amnesty International Report 1999: Rwanda, supra note 121; 1999 State Department Human Rights Report on Rwanda, supra note 112.

${ }^{148}$ See 1999 Report of the Special Representative of the UNCHR, supra note 136, paras. 56-70.

${ }^{149} \mathrm{Ibid}, \mathrm{p} .57$.

${ }^{150}$ Report of the Secretary-General on the Situation in Burundi, UN SCOR, 51st Sess, para 3, UN Doc $\mathrm{S} / 1996 / 116$ (1996).
} 


\section{Conclusion}

The UN and the international community were initially lulled into thinking that justice would come to Rwanda with an 'effective' ICTR, which was succeeding in securing custody of many of its indictees. A few years down the road, it was clear that the genocide in Rwanda was in fact the product of years of human rights violations ${ }^{151}$ and that an intense, creative, and sustained intervention involving the Rwandan government, civil society actors, UN entities, international financial institutions, and bilateral funding agencies was therefore needed to address the full spectrum of human rights.

If the ideal is to facilitate positive social change in Rwanda that brings about reconciliation and the respect for human rights, a system based on ill-thought-out symbolic justice or attainable mass retribution had to be re-oriented with a more thought-out and creative strategy regarding the structure and operation of the ICTR and a synergy with Rwandan domestic penal process. An actor-oriented perspective alone cannot prevent future human rights violations in Rwanda. It is unable to react adequately to social evils built into the social structure of the Rwandan society. The experience of the past nine years shows that the vicious cycle of violence, though somewhat muted, is very much alive. ${ }^{152}$ The Gacaca system provides an innovative and practical blend of retributive and restorative justice since it is within communities that most of the atrocities took place during the genocide yet victims were initially largely alienated from the international and domestic by distance, procedure and lack of

\footnotetext{
${ }^{151}$ For example, the lack of sufficient access to quality public education created some of the conditions whereby leaders could manipulate large portions of the population; these leaders promoted the lack of tolerance and institutionalised difference between societal groups.

${ }^{152}$ A leader of one of the opposition groups composed mainly of Hutu extremists in an interview stated that the struggle will never end equating the laying down of arms before their demands are met which inter alia include the return to the 1992 Constitution as amounting to an acceptance of guilt to some
} 
communication. "Because Gacaca is based on local culture, it is likely to create from the beginning a greater sense of familiarity, respect, trust and commitment to the process than the Western judicial system. As members of the community, Gacaca judges will have a sense of the full measure of injury that the community has suffered and can lead hearings to address those facts." 153 However there are valid grounds that despite its overall philosophy based on traditional dispute resolution, the system has significant penal characteristics albeit with few or no procedural safeguards against error or abuse. ${ }^{154}$ The Rwandan government must maintain active vigilance over the process lest it becomes a conduit for settling scores-real and imagined.

It is evident that the ugliness of the genocidal conflagration and the political reality of the ethnic hatred cannot be isolated into an international courtroom for resolution. The ICTR stands to make more sense if it was part of a comprehensive domestic and international process of punishment, reconstruction, and reconciliation. The Rwandan have a greater understanding of what is necessary to ensure that prosecutions meet the nation's most important objectives. They are the people in struggle and cooperation, in association and disassociation. A complementary twin approach by the national and international penal process through a synchronic formula is likely to hit at the volatile polarised structure by challenging it through judicial activity. This will contribute to the Rwandan seeing their divided socio-political structure as one of the primary sources of their tragedy and try and withdraw or change it. The ICTR has had positive influences on the Rwandan national trials through allowing 'raw' Rwandan judges with little legal

crime. See 'Rebel Leader Says He Is Not In Arusha to Negotiate', Internews, 24 July 2000, http://www.africanews.org/rwanda/ stories, visited 30 March 2001.

${ }^{153}$ Ironside, supra note 124 , p. 49. 
experience to attend ICTR trial sessions a move that is of enormous benefit to the newly trained jurists. In addition the ICTR has increasingly turned to a policy of generally enforcing its sentences in African prisons. ${ }^{155}$ The aim is not only to correct its image in Rwanda and Africa as a multi-million dollar Western conscience cleaning exercise but also to shed its image as a ritzy court that guarantees the guilty tickets to 'luxurious' European prisons. In addition it seeks to have a greater deterrent effect against impunity Africa, a continent that has largely come to be associated with despotic rulers, civil strife and sovereign excesses.

Even as the Rwandan government moves to try individuals handed over from the ICTR, it ought to bear in mind the need to both chastise the Hutus but also absolve the entire community indefinitely of guilt. As long as the individuals on the dock are seen in the wider context of the guilt of a community, the prosecutions can only lead to less chances of reconciliation and re-integration. More so as the individuals cut across various spectra of Rwandan society-military commanders and politicians, civilian administrators, the clergy and journalists thus seemingly representing a guilt that transcends all levels to cover each and every social rung of the Hutus. The Rwandan government, especially the judicial branch, should continue to take steps to ensure the legitimacy of its national genocide trials. The Rwandan society will benefit from fair and neutral judicial process than quick trials that seem to reflect political expedience as opposed to law. If the Rwandan justice system does not establish itself as a fair and just system, it could just as easily contribute to the cycle of vengeance as it could to ending it. On going conflict in the region and atrocities over which the ICTR has no jurisdiction

\footnotetext{
154 See Carroll, supra note 102, p. 192; see E. Daly, 'Transformative Justice: Charting a Path to
} Reconciliation', 12 International Legal Perspectives (2001/02) p. 179. 
should fall within the purview of the domestic justice process which is not straitjacketed by a Security Council mandate as the ICTR is. Selective enforcement of the law against Hutu's will not help dispel the ethnic venom of hatred which needs to be dispelled through both positive political goodwill as well as legal impartiality. ${ }^{156}$

The establishment of the ICTR and its singular focus on the prosecution of a miniscule fraction of the perpetrators of the genocide was initially a woefully inadequate way to redress the brutal murder of millions of Rwandans. However, the ICTR's initially sterile approach has subsequently been supplemented by conflict management and resolution measures. These developments have been important in laying ground for a new paradigm combining the actor-oriented and structure-oriented perspectives, promoting an international law that truly permeates the human populace, not stopping at the gates of the State but bridging the gap between collective and individual actors better than it had done before. The key condition for such change is consciousness, and more sensitivity to the actor-structure relationship. Alongside trials, the outreach centre will facilitate dissemination of information that will help the two communities understand the weakness of the social structure and help ensure that the Rwanda situation is not simply a change of guard, one ethnic hegemony for another.

\footnotetext{
${ }^{155}$ See generally, ICTR Statute, art. 23.

156 The Commission of Experts, established by the United Nations in 1994 to investigate crimes in Rwanda, concluded in their report that although they were unable to uncover any evidence that Tutsis had intended to destroy the Hutu ethnic group within the meaning of the Genocide Convention of 1948, there was overwhelming evidence to prove that Tutsis has committed crimes against humanity and serious violations of international humanitarian law. See Report of the Commission of Experts on the Evidence of Grave Violations of International Humanitarian Law in Rwanda, Including Possible Acts of Genocide, S/1994/1125, 4 October 1994, paras. 93-100, 185-86.
} 